\title{
Miskonsepsi IPA biologi pada guru kelas IV sekolah dasar
}

\author{
Lidwina Tutusari Mieke *, Wahyu Wido Sari, Eny Winarti \\ Program Studi Pendidikan Guru Sekolah Dasar, FKIP, Universitas Sanata Dharma, \\ Kampus II Jl. Affandi, Mrican Tromol Pos 29 Yogyakarta 55281 \\ lidwina.tutusari@gmail.com \\ *korespondensi penulis
}

\begin{abstract}
Abstrak
Miskonsepsi merupakan salah satu penyebab rendahnya nilai pada suatu mata pelajaran pada siswa. Salah satu faktor miskonsepsi pada siswa adalah guru. Penelitian ini bertujuan untuk memaparkan mengenai miskonsepsi yang terjadi pada guru wali kelas di SD N Purnama (bukan nama sebenarnya), khususnya pada mata pelajaran IPA Biologi. Partisipan pada penelitian ini dibagi menjadi dua yaitu partisipan utama (Bapak Agung dan Ibu Sari) dan partisipan lain (siswa kelas IV). Teknik pengumpulan data untuk penelitian ini menggunakan triangulasi data, yaitu observasi, wawancara mendalam, dan studi dokumentasi.

Metode pada penelitian ini adalah fenomenologi. Fenomenologi terbagi menjadi dua langkah, yaitu epoche dan reduksi. Epoche atau pemutusan hubungan dilakukan pada saat wawancara mendalam kepada partisipan utama (guru wali kelas) dan partisipan lainnya (siswa kelas IV). Sedangkan reduksi data merupakan langkah yang dilakukan peneliti pada saat membandingkan data yang diperoleh (hasil pemahaman guru, siswa, dan teori tertulis).

Penelitian ini mendapatkan hasil bahwa Bapak Agung mengalami miskonsepsi sebesar 25\%, Ibu Sari mengalami miskonsepsi 36\%, dan miskonsepsi pada siswa memiliki hubungan dengan miskonsepsi yang terjadi pada guru.
\end{abstract}

Kata kunci: Miskonsepsi, IPA, Biologi, Guru, Sekolah Dasar

\section{Abstract}

Misconception is one of the causes of low grades in a subject in students. One of the factors of misconception in students is the teacher. This study aims to explain the misconceptions that occur in homeroom teachers in Purnama Elementary Elementary School (not real names), especially in Biology Science subjects. Participants in this study were divided into two, namely the main participants (Mr. Agung and Mrs. Sari) and other participants (grade IV students). Data collection techniques for this study used data triangulation, namely observation, in-depth interviews, and documentation studies.

The method in this research is phenomenology. Phenomenology is divided into two steps, namely epoche and reduction. Epoche or termination is done during in-depth interviews with the main participant (homeroom teacher) and other participants (fourth grade students). While data reduction is a step taken by researchers when comparing the data obtained (the results of the understanding of teachers, students, and written theory).

This study found that Mr. Agung experienced a misconception of $25 \%$, Mrs. Sari experienced a misconception of $36 \%$, and misconceptions among students had a relationship with misconceptions that occurred with teachers.

Keywords: Misconception, Natural Sciences, Biology, Teachers, Elementary Schools 


\section{PENDAHULUAN}

The International Association for the Evaluation of Educational Achievement (IEA) yang merupakan organisasi internasional yang bekerja sama dengan institusi penelitian nasional dan agensi pemerintahan yang telah menyelenggarakan studi pencapaian antar negara sejak 1959 (KEMENDIKBUD). Organisasi ini mengadakan sebuah studi yaitu Trends in International Mathematics and Science Study atau TIMSS. Diketahui bahwa TIMSS diselenggarakan guna membandingan prestasi matematika dan IPA pada siswa kelas IV di sekolah dasar dan kelas VIII di sekolah menengah pertama. Pada tahun 2015, negara yang turut berpartisipasi dalam TIMSS yaitu sebanyak 48 negara termasuk Indonesia. Pada survei ini Indonesia menempati rangking ke 46 dari 48 negara sehingga dapat dikatakan bahwa prestasi IPA tergolong rendah jika dilihat dari rangking dibandingkan dengan negara lain.

Fakta mengenai rendahnya prestasi IPA berdasarkan TIMSS tersebut membuat peneliti tertarik untuk melakukan tanya jawab di SD N Purnama (nama sekolah disamarkan). Tanya jawab ini guna untuk mengetahui pemahaman dalam pelajaran IPA. Sekolah ini termasuk 10 besar sekolah yang memiliki nilai rata-rata UN tertinggi dan nilai rata-rata IPA pada ujian nasional pada tiga tahun berturut selalu diatas KKM, yaitu 91,56 pada tahun 2016, 85,51 pada tahun 2017, dan 84,29 pada tahun 2018.

Partisipan yang akan ditanya adalah siswa SD kelas IV. Tanya jawab ini berupa materi pelajaran IPA Biologi di sekolah dasar. Pertanyaannya yaitu; "Apakah semua tanaman bisa berfotosintesis?". Tiga dari lima anak yang ditanya menjawab bahwa, "ya,semua tanaman bisa berfotosintesis". Pertanyaan lain yang dilontarkan oleh peneliti yaitu; "apakah setiap tanaman memiliki akar, batang, dan daun?" kemudian, lima dari lima anak membenarkan bahwa setiap tanaman memiliki akar, batang, dan daun.

Kesalahan konsep yang dialami oleh siswa disebut dengan miskonsepsi. Dalam Suparno (2005: 4) miskonsepsi atau salah konsep menunjuk pada suatu konsep yang tidak sesuai dengan pengertian ilmiah atau pengertian yang diterima oleh pakar dalam bidang. Miskonsepsi yang dimiliki siswa dapat menyebabkan rendahnya nilai dalam menjawab soalsoal mengenai konsep pelajaran. Selain itu miskonsepsi pada siswa dapat pula memberikan menyebabkan siswa yang lainnya mengalami miskonsepsi pula.

Miskonsepsi yang terjadi pada siswa dapat diminimalisir atau diperbaiki oleh guru. Hal ini dibuktikan dalam UU nomor 1 tahun 2005 tentang guru dan dosen pasal 1 ayat 1, yang menyatakan bahwa; "guru adalah pendidikan profesional dengan tugas utama mendidik, mengajar, membimbing, mengarahkan, melatih, menilai, dan mengevaluasi peserta didik 
pada pendidikan anak usia dini jalur pendidikan formal, pendidikan dasar, dan pendidikan menengah. Jadi dapat dikatakan bahwa guru turut mengambil peran besar dalam pemahaman konsep IPA pada siswa. Guru sebagai tenaga profesional seharusnya menguasai bahan pelajaran, karena penguasaan materi pelajaran termasuk dalam salah satu dari 10 kompetensi guru.

\section{METODE}

Penelitian ini dilaksanakan pada saat peneliti melaksanakan kegiatan program pengalaman lapangan atau PPL pada semester genap tahun ajaran 2018/2019. Metode dalam penelitian ini menggunakan metode fenomenologi. Teknik pengumpulan data untuk penelitian ini menggunakan triangulasi data, yaitu observasi, wawancara mendalam, dan studi dokumentasi. Sementara teknik analisa data terdapat dua tahap, yaitu epoche dan reduksi. Epoche atau pemutusan hubungan dilakukan pada saat wawancara mendalam kepada partisipan utama (guru wali kelas) dan partisipan lainnya (siswa kelas IV). Sedangkan reduksi data merupakan langkah yang dilakukan peneliti pada saat membandingkan data yang diperoleh (hasil pemahaman guru, siswa, dan teori tertulis).

\section{HASIL DAN PEMBAHASAN}

\section{Guru Wali Kelas IV}

Berdasarkan hasil wawancara dan perbandingan teori pada buku dan jurnal yang sudah dibahas sebelumnya, peneliti mndapatkan hasil jawaban kedua sebagai berikut;

Tabel 1: Rangkuman hasil wawancara partisipan utama

\begin{tabular}{|c|c|c|c|c|c|}
\hline & MISKONSESI IPA & DLOG & & & \\
\hline & Pertanyaan & Bap & Agung & & ari \\
\hline & Pertanyaan & $\mathrm{Ya}$ & Tidak & Ya & Tidak \\
\hline & $\begin{array}{l}\text { Apakah akar serabut merupakan ciri tanaman } \\
\text { dikotil? }\end{array}$ & - & $\sqrt{ }$ & $\sqrt{ }$ & - \\
\hline 2. & Apakah setiap tanaman memiliki bunga? & - & $\sqrt{ }$ & - & - \\
\hline 3. & $\begin{array}{l}\text { Apakah setiap tanaman yang berbuah memiliki } \\
\text { bunga? }\end{array}$ & - & - & - & - \\
\hline 4. & Apakah nektar dan madu adalah sama? & $\sqrt{ }$ & - & - & $\sqrt{ }$ \\
\hline 5. & Apakah setiap tanaman memiliki zat klorofil? & - & $\sqrt{ }$ & $\sqrt{ }$ & - \\
\hline 6. & $\begin{array}{l}\text { Apakah semakin banyak zat klorofil di dalam daun } \\
\text { akan menyebabkan daun semakin berwarna } \\
\text { hijau? }\end{array}$ & - & $\sqrt{ }$ & - & $\sqrt{ }$ \\
\hline 7. & $\begin{array}{l}\text { Apakah karbondioksida dalam proses fotosintesis } \\
\text { hanya dapat diperoleh dari mulut daun/stomata } \\
\text { saja? }\end{array}$ & - & - & $\sqrt{ }$ & - \\
\hline 8. & $\begin{array}{l}\text { Apakah bayam termasuk dalam golongan batang } \\
\text { basah? }\end{array}$ & - & $\sqrt{ }$ & - & - \\
\hline
\end{tabular}




\begin{tabular}{|c|c|c|c|c|}
\hline \multicolumn{5}{|c|}{ MISKONSESI IPA BIOLOGI } \\
\hline \multirow{2}{*}{ Pertanyaan } & \multicolumn{2}{|c|}{ Bapak Agung } & \multicolumn{2}{|c|}{ Ibu Sari } \\
\hline & Ya & Tidak & Ya & Tidak \\
\hline 9. Apa perbedaan akar tunjang dan akar napas? & $\sqrt{ }$ & - & $\sqrt{ }$ & - \\
\hline 10. Fungsi penyerbukan pada bunga? & - & - & - & $\sqrt{ }$ \\
\hline $\begin{array}{l}\text { 11. Apakah semua buah memiliki struktur biji, daging, } \\
\text { kulit, dan tangkai? }\end{array}$ & - & - & - & $\sqrt{ }$ \\
\hline $\begin{array}{l}\text { 12. Apakah setiap tumbuhan memiliki tiga bagian } \\
\text { pokok tubuh tumbuhan seperti akar, batang, dan } \\
\text { daun? }\end{array}$ & - & $\sqrt{ }$ & - & $\sqrt{ }$ \\
\hline $\begin{array}{l}\text { 13. Apakah katak dewasa hanya bernafas } \\
\text { meggunakan paru-paru? }\end{array}$ & - & $\sqrt{ }$ & - & $\sqrt{ }$ \\
\hline $\begin{array}{l}\text { 14. Apakah ada hewan yang tidak mengalami } \\
\text { metamorfosis? }\end{array}$ & - & - & - & $\sqrt{ }$ \\
\hline 15. Apakah abrasi dan erosi itu sama? & $\sqrt{ }$ & & - & $\sqrt{ }$ \\
\hline 16. Perbedaaan biodiesel dan bioetanol? & & $\sqrt{ }$ & & $\sqrt{ }$ \\
\hline $\begin{array}{l}\text { 17. Apakah pembuatan kompos secara alami atau } \\
\text { dengan cara menimbun sampah organik di dalam } \\
\text { tanah dapat merusak unsur tanah? }\end{array}$ & & $\sqrt{ }$ & $\sqrt{ }$ & - \\
\hline
\end{tabular}

Berikut pembahasan mengenai instrumen pertanyaan yang mengalami miskonsepsi: Bapak Agung

Bapak Agung mengalami miskonsepsi pada tiga pertanyaan. Pertama "Apa perbedaan akar tunjang dan akar napas? begitu pertanyaan pertama yang dilontarkan peneliti. Kemudian Bapak Agung langsung menjawab Akar tunjang itu hanya menyokong tegaknya tubuh sih, contoh di pantai. Lihat pandan? Lalu peneliti menjawab "iya". Pak Agung melanjutkan, "itu selain di dalam dia akan ada akar yang keluar dari atas, sebelum sampai tanah ia akan napas, tapi begitu dalam tanah ia jadi akar murni, dia menyokong dan menjadi akar tunjang. Termasuk bakau itu bukan akar tunjang. Dia tumbuh dari atas ke bawah, menyokong tegaknya tubuh, menunjang, namanya akar tunjang. Sebenarnya hanya istilah itu saja" Begitu kata Bapak Agung. Dalam Haryanto (2013: 15) menjelaskan bahwa akar tunjang merupakan akar dari bagian bawah batang ke segala arah dan akar napas merupakan akar yang tumbuh tegak lurus ke atas sehingga muncul dari permukaan tanah atau air. Berdasarkan kutipan tersebut dapat dikatakan bahwa Bapak Agung mengalami kesalahpahaman mengenai akar napas sama seperti pada saat wawancara pertama.

Selanjutnya peneliti menanyakan pertanyaan dari materi yang terakhir yaitu keseimbangan dan pelestarian alam pada kompetensi dasar 3.8 menjelaskan pentingnya upaya keseimbangan dan pelestarian sumber daya alam di lingkungannya. Pertanyaan pertama yang ditanyakan yaitu "apakah abrasi dan erosi itu sama?" kemudian guru memberikan tanggapan berupa jawaban sebagai berikut "abrasi dan erosi merupakan samasama pengerusakan alam akibat pengikisan air". Sumantoro dan Hermana (2013: 194) terdapat dua kalimat yang mengatakan bahwa; hujan dapat menyebabkan erosi, banjir, dan 
tanah longsor; dan gelombang air laut dapat menyebabkan abrasi. Jika dibandingkan dalam teori tersebut dapat dikatakan Bapak Agung mengalami miskonsepsi karena dijelaskan bahwa penyebab abarsi dan erosi adalah berbeda.

Terakhir,"apakah nektar dan madu adalah sama", bagi Bapak Agung nektar dan madu adalah sama. Hal ini terlihat dari jawaban Bapak Agung, yaitu "nektar itu bahasa latin, sebenarnya juga madu. Lebah itu bukan membuat madu, dia kan mengambil nektar, nanti dikumpulkan ke sarangnya untuk anak-anaknya atau koloninya, ya kalau di cek nanti dalam kamus bahasa Indonesia itu "nektar” itu bahasa aslinya darimana. Itu dipunggut menjadi bahasa Indonesia. Banyak dari bahasa Inggris atau bahasa daerah yang dipunggut menjadi bahasa Indonesia misalnya. Dalam Evahelda dkk. (2017: 263) madu merupakan cairan alami yang umumnya manis, berasal dari nektar bunga yang dikumpulkan oleh lebah madu. Disimpulkan bahwa Bapak Agung mengalami kesalahpahaman konsep mengenai materi ini sama seperti tanggapan saat pertanyaan ini dilontarkan pada waktu sebelumnya.

\section{Ibu Sari}

Ibu Sari mengalami 5 miskonsepsi. Pertanyaan pertama yaitu. apakah akar serabut merupakan ciri tanaman dikotil?" Kemudian Ibu Sari merespon dengan jawaban seperti berikut "kalau serabut dikotil? Kalau pengertian di sini pasti iya." Peneliti merasa kurang puas untuk jawaban yang diberikan guru dan mengajukan pertanyaan di luar instrumen untuk menggali lebih dalam mengenai pemahaman materi Ibu Sari, yaitu "bedanya tanaman dikotil dan monokotil itu apa ya bu?" Kemudian Ibu Sari memberikan respon berupa jawaban “cuma itunya, apa namanya? bijinya. Tapi anak-anak monokotil dan dikotil kelas 4 itu hanya belajar mengenai bentuk akar dan tulang jadi belum terlalu yang monokotil gimana dan dikotil gimana." Setelah melakukan pengecekan pada sebuah buku, dalam Haryanto (2016: 14) akar serabut dimiliki oleh tumbuhan biji berkeping satu (monokotil), misalnya jagung dan tebu. Berdasarkan teori tersebut peneliti menyimpulkan bahwa Ibu Sari mengalami miskonsepsi dengan jawaban bahwa tanaman dikotil memiliki akar serabut pedahal teori mengatakan bahwa akar dikotil memiliki akar tunggang.

Kemudian peneliti menanyakan "apakah setiap tanaman memiliki zat klorofil?" Ketika peneliti menanyakan lagi "pasti ya bu?" Ibu Sari kembali merespon dengan jawaban pendek "he'em." Dalam Shohib (2017: 34) Ciri-ciri jamur yaitu tidak memiliki klorofil sehingga bersifat heterotrof. Peneliti menyimpulkan bahwa terdapat tumbuhan yang tidak memiliki klorofil sehingga jawaban Ibu Sari pada pertanyaan nomor satu mengalami miskonsepsi. 
Pertanyaan ketiga yang direspon "he'em" adalah "apakah karbondioksida dalam proses fotosintesis hanya dapat diperoleh dari mulut daun/stomata saja?" Ketika peneliti bertanya “pasti ya bu?" Guru kembali bergumam “he'em” sambil menganggukan kepalanya. Dalam Priyono, dkk (2009) tertulis bahwa penyerapan gas karbondioksida dilakukan oleh tumbuhan melalui stomata dan lentisel. Peneliti menyimpulkan bahwa penyerapan karbondioksida tidak hanya diperoleh dari mulut daun/stomata saja sehingga jawaban Ibu Sari untuk pertanyaan nomor 3 mengalami miskonsepsi.

Selanjutnya yaitu "apa perbedaan akar tunjang dan akar napas?" dan guru memberikan respon "akar tunjang itu yang di bakau itu kan? Kalau akar nafas itu ga harus itu kan?" begitu ujarnya sambil memiringkan kepalanya sedikit dan mengerutkan alisnya. Setelah jawaban tersebut diberikan guru tidak memberikan jawaban lagi dan menatap peneliti untuk beberapa saat hingga terjadi keheningan sampai peneliti memutuskan untuk melontarkan pertanyaan selanjutnya. Dalam Haryanto (2013: 15) menjelaskan bahwa akar tunjang merupakan akar dari bagian bawah batang ke segala arah dan akar napas merupakan akar yang tumbuh tegak lurus ke atas sehingga muncul dari permukaan tanah atau air. Respon yang diberikan Ibu Sari kurang menjawab pertanyaan yang diberikan peneliti, namun memang benar bahwa tumbuhan bakau memiliki akar tunjang. Melihat dari sikap yang dilakukan nampaknya Ibu Sari memiliki keraguan. Hal itu nampak pada saat beliau menjawab dengan kalimat yang terdapat pemberhentian setiap katanya dan malah bertanya balik kepada peneliti. Peneliti menyimpulkan bahwa Ibu Sari mengalami miskonsepsi dalam materi ini.

Kemudian pertanyaan terakhir dilontarkan oleh peneliti, “apakah pembuatan kompos secara alami atau dengan cara menimbun sampah organik di dalam tanah dapat merusak unsur tanah?" Jawaban yang diberikan guru adalah "enggak kan, semua makhluk hidup kan asalnya dari tanah. Jadi kalau kembali ke tanah pasti tidak merusak tanah kan" begitu jawab Ibu Sari dengan penekanan kata "kan" pada akhir kalimatnya. Jawaban yang diberikan oleh Ibu Sari bisa dikatakan kurang ilmiah, secara biologis tidak mungkin makhluk hidup berasal dari tanah. Namun untuk pertanyaan ini memang benar jika makhluk hidup yang sudah mati yang kemudian akan ditimbun tanah sehingga menjadi kompos tidak akan merusah unsur tanah. Dalam Shohib (2017: 72) pengurai merupakan makhluk hidup yang mampu menguraikan zat-zat pada makhluk hidup yang sudah mati untuk menjadi sumber makanannya. Jadi dapat disimpulkan bahwa jika pembuatan kompos yang merupakan penimbunan sampah organik tersebut akan dimakan oleh pengurai sehingga tidak merusak tanah. Jawaban yang diberikan Ibu Sari benar bahwa pembuatan kompos menggunakan cara 
menimbun sampah organik dalam tanah tidak merusak tanah, namun jika dipandang dari teori ilmiah Ibu Sari mengalami miskonsepsi bahwa makhluk hidup berasal dari tanah.

Siswa

Hasil wawancara yang dilakukan kepada partisipan utama mendapatkan hasil bahwa terdapat enam pertanyaan yang mengalami miskonsepsi, yaitu pertanyaan nomor 1, 4, 5, 7, 9, dan 17. Enam pertanyaaan tersebut merupakan gabungan dari pertanyaan yang mengalami miskonsepsi dari kedua guru. Selanjutnya pertanyaan tersebut akan ditanyakan kepada partisipan lain atau siswa melalui wawancara. Berikut hasil wawancara yang dilakukan kepada siswa:

a. Siswa Kelas Ceria (bukan nama sebenarnya)

Pada siswa Kelas Ceria atau siswa Bapak Agung terdapat tiga pertanyaan yang ditanyakan. Hal ini sesuai dengan pertanyaan yang terjadi miskonsepsi pada Bapak Agung. Pertanyaan pertama yaitu, "apakah nektar dan madu adalah sama?" Pertanyaan tersebut mendapatkan respon yaitu 7 dari 11 siswa menjawab bahwa nektar dan madu adalah sama. "Sama bu, kan sama-sama cair dan manis, kaya di bunga yang merah panjang itu" begitu resspon siswa pertama. "Jelas sekali beda, kan nektar di bunga, diambil lebah baru jadi madu eyang kakung bilang gitu, baru di jual jadi madu kurma TJ" katanya sambil mengerutkan alis. Selain itu ada juga yang berkata, "sama bu, kemarin ada Bapak Agung jelaskan" Begitu salah satu pernyataan dari siswa tersebut. Siswa lain berkata "Pak Agung bilang sih sama bu. Kalau tidak salah yo bu, lupa-lupa bu. Hahahaha” ujar siswa lain sambil tertawa-tawa.4 dari 11 siswa menjawab bahwa nektar dan madu adalah beda. "Di buku paket bilangnya beda bu", "ya beda no bu, nektar tu di bunga, madu ya di sarang lebah", dan "beda bu" begitu pernyataan dari salah satu siswa. Dalam Evahelda, dkk. (2017: 363) madu merupakan cairan alami yang umumnya manis, berasal dari nektar bunga yang dikumpulkan lebah madu. Berdasarkan dari pendapat yang dikemukakan siswa diketahui bahwa 7 dari 11 siswa mengalami miskonsepsi dan 4 dari 11 siswa tidak mengalami miskonsepsi.

Pada pertanyaan selanjutnya yaitu “apa perbedaan akar tunjang dan akar napas?". Pertanyaan tersebut mendapatkan respon sebagai berikut 1 dari 10 siswa memberikan jawaban "akar tunjang itu yang ada di tanaman dekat pantai yang mirip pandan, kalau napas ndak tau". 7 dari 10 anak menjawab tidak tahu. 2 dari 10 anak merespon pertanyaan dengan senyuman. Dalam Haryanto (2013: 15) menjelaskan bahwa akar tunjang merupakan akar dari bagian bawah batang ke segala arah dan akar napas merupakan akar yang tumbuh 
tegak lurus ke atas sehingga muncul dari permukaan tanah atau air. Berdasarkan dari pendapat yang dikemukakan siswa diketahui bahwa siswa menjawab tidak sesuai dengan pertanyaan, menjawab tidak tahu, dan ada pula yang memberikan tanggapan berupa senyuman saja. Oleh sebab itu peneliti tidak mengkategorikannya dalam miskonsepsi dan tidak juga membenarkan tanggapan siswa tersebut.

Pertanyaan terakhir yang ditanyakan yaitu, “Apakah abrasi dan erosi itu sama?”. Respon yang diberikan siswa yaitu, 5 dari 10 anak menjawab abrasi dan erosi itu beda. "penyebab abrasi itu yo ombak, erosi itu hujan" begitu salah satu pernyataan siswa. Siswa kedua menjawab "abrasi ki sebab e ombak, makane di pantai tu ada segitiga-segitiga kaya di Glagah, tempate mbah", ujarnya. "erosi tu sebabnya hujan, abrasi tu ombak" begitu kata siswa ketiga. 3 dari 10 anak menjawab sama. "sama-sama kerusakan oleh hujan" dan dibenarkan oleh 2 anak lainnya. 2 dari 10 anak menjawab tidak tahu. Sumantoro dan Hermana (2013: 194) terdapat dua kalimat yang mengatakan bahwa; hujan dapat menyebabkan erosi, banjir, dan tanah longsor; dan gelombang air laut dapat menyebabkan abrasi. Berdasarkan kutipan tersebut peneliti menyimpulkan bahwa 3 dari 10 siswa mengalami miskonsepsi, 5 dari 10 siswa tidak mengalami miskonsespi, dan 2 dari 10 anak tidak termasuk keduanya (tidak menjelaskan konsep yang diketahuinya)

b. Siswa Kelas Cermat (bukan nama sebenarnya)

Pada siswa Kelas Cermat atau siswa Ibu Sari terdapat lima pertanyaan yang ditanyakan. Pertanyaan yang pertama yaitu "apakah akar serabut merupakan ciri tanaman dikotil?" Respon pertanyaan ini yaitu, 9 dari 10 siswa menjawab bahwa akar serabut dimiliki oleh tanaman monokotil. "serabut itu monokotil, kaya padi, dia biji satu, akarnya serabut kan bu”, "serabut, serabut, ada di padi kata Bu Sari, bijinya satu jadi mono, ya benar bu", "serabut ki monokotil yo bu", dan "yo nek serabut, monokotil, piye to bu" ujarnya sambil memperlihatkan LKS yang dimilikinya. Begitu respon pernyataan dari siswa yang menjawab. 1 dari 10 siswa menjawab tidak tahu. Haryanto (2016: 14) akar serabut dimiliki oleh tumbuhan biji berkeping satu (monokotil), misalnya jagung dan tebu. Berdasarkan kutipan tersebut 9 dari 10 siswa tidak mengalami miskonsepsi dan 1 dari 10 siwa tidak termasuk miskonsepsi maupun sudah sesuai dengan konsep.

Selanjutnya yaitu, “Apakah setiap tanaman memiliki zat klorofil?” Respon yang diberikan oleh siswa yaitu, 7 dari 11 siswa mengatakan bahwa setiap tanaman memiliki zat klorofil. "Kan tanaman merupakan makhluk hidup yang bisa membuat makanannya sendiri, jadi pasti ada klorofil"dan "ada lah bu, kan due daun". 2 dari 11 siswa menjawab tidak tahu dan dengan senyum mengatakan "lupa $e$ bu" dan dibenarkan oleh temannya. 1 siswa 
menjawab dengan senyuman. Dalam Shohib (2017: 34) ciri-ciri jamur yaitu tidak memiliki klorofil sehingga bersifat heterotrof. Berdasarkan ahli di atas diketahui bahwa 7 dari 11 siswa tidak mengalami miskonsepsi dan 4 dari 11 siswa tidak termasuk miskonsepsi maupun sudah sesuai dengan konsep.

Pertanyaan selanjutnya masih berkaitan dengan tumbuhan hijau adalah "apakah karbondioksida dalam proses fotosintesis hanya dapat diperoleh dari mulut daun/stomata saja?" Pertanyaan tersebut mendapatkan respon, 1 dari 8 siswa mengatakan "aku ada baca LKS, ada lubang di batang yang bisa ambil karbondioksida lho bu". 7 dari 8 siswa mengatakan iya dengan respon berupa anggukan kepala yang perlahan dan ada juga yang menjawab iya setelah berpikir beberapa detik. Dalam Priyono, dkk (2009) tertulis bahwa penyerapan gas karbondioksida dilakukan oleh tumbuhan melalui stomata dan lentisel. Peneliti menyimpulkan bahwa 7 dari 8 siswa mengalami miskonsepsi dan 1 dari 8 siswa tidak mengalami miskonsepsi.

“Apa perbedaan akar tunjang dan akar napas?” Pertanyaan ini merupakan pertanyaan yang dilontarkan pada siswa Kelas Ceria pula karena kedua guru sama-sama memiliki miskonsepsi pada pertanyaan ini. Respon siswa Kelas Cermat pada pertanyaan ini yaitu, 3 dari 11 siswa memberikan jawaban serupa yaitu akar tunjang keluar dari batang sementara akar napas keluar dari tanah. Beikut respon siswa "akar tunjang itu bu, dia buat menunjang, yang di kiri kanan pohon bakau” katanya sambil menganguk-angukan kepalanya "yang nafas tu akar yang keluar dari tanah, dia berdiri-diri bu" Begitu lanjutan ucapannya. Siswa kedua berkata, "bedanya ya bu?, sama-sama di bakau to ya kan Nan?" Katanya sambil melihat temannya. "iya kan tunjang ki di kiri kanannya no, nek nafas ki yang di...” jawab teman siswa kedua. Sebelum temannya selesai berbicara siswa kedua memotong "oh iya. Tunjang kiri kanan pohon, nafas tu yang di tanah, keluar dari tanah e bu" ujarnya. 8 dari 11 anak menjawab dengan jawaban "tidak tahu" "mboh bu" dan gelengan kepala. Dalam Haryanto (2013: 15) menjelaskan bahwa akar tunjang merupakan akar dari bagian bawah batang ke segala arah dan akar napas merupakan akar yang tumbuh tegak lurus ke atas sehingga muncul dari permukaan tanah atau air. Kutipan tersebut memberikan bukti bahwa 3 dari 11 siswa tidak mengalami miskonsepsi dan 8 dari 11 siswa tidak termasuk miskonsepsi maupun sudah sesuai dengan konsep.

Pertanyaan terakhir untuk siswa Kelas Cermat adalah "apakah pembuatan kompos secara alami atau dengan cara menimbun sampah organik di dalam tanah dapat merusak unsur tanah?" Pertanyaan tersebut mendapatkan respon, 7 dari 10 siswa menjawab bahwa 
pembuatan kompos secara alami atau dengan cara menimbun sampah organik di dalam tanah tidak dapat merusak unsur tanah. Berikut beberapa pernyataan siswa: "sampah organik kaya sampah pisang bikin tanahnya subur bu”, "ya enggak to bu kan kan bikin subur", "tidak rusak bu, dan jadinya tanahnya itu ya jadinya ya subur bisa tanam bunga, ibu". 2 dari 10 siswa manjawab tidak tahu. 1 dari 10 siwa menjawab dengan senyuman. Dalam Shohib (2017: 72) pengurai merupakan makhluk hidup yang mampu menguraikan zat-zat pada makhluk hidup yang sudah mati untuk menjadi sumber makanannya. Kesimpulan pada pertanyaan terakhir yaitu 7 dari 10 siswa tidak mengalami miskonsepsi dan 3 dari 10 siswa tidak termasuk miskonsepsi maupun sudah sesuai dengan konsep.

Berikut pendataan mengenai miskonsepsi yang terjadi kepada partisipan lain atau siswa;

Tabel 1: Rangkuman hasil wawancara partisipan lain

\begin{tabular}{|c|c|c|c|c|}
\hline \multirow{2}{*}{ Pertanyaan } & $\begin{array}{l}\text { SI IPA BIO } \\
\text { Bapak }\end{array}$ & $\begin{array}{l}\text { OGI } \\
\text { gung }\end{array}$ & \multicolumn{2}{|c|}{ Ibu Sari } \\
\hline & $\mathrm{Ya}$ & Tidak & Ya & Tidak \\
\hline $\begin{array}{l}\text { 1. Apakah akar serabut merupakan ciri } \\
\text { tanaman dikotil? }\end{array}$ & & & - & $\begin{array}{l}9 \text { dari } 10 \\
\text { siswa }\end{array}$ \\
\hline 2. Apakah nektar dan madu adalah sama? & 7 dari 11 & 4 dari 11 & & \\
\hline $\begin{array}{l}\text { 3. Apakah setiap tanaman memiliki zat } \\
\text { klorofil? }\end{array}$ & & & $\begin{array}{l}7 \text { dari } 11 \\
\text { siswa }\end{array}$ & * \\
\hline $\begin{array}{l}\text { 4. Apakah karbondioksida dalam proses } \\
\text { fotosintesis hanya dapat diperoleh dari } \\
\text { mulut daun/stomata saia? }\end{array}$ & & & $\begin{array}{l}7 \text { dari } 8 \\
\text { siswa }\end{array}$ & $\begin{array}{l}1 \text { dari } 8 \\
\text { siswa }\end{array}$ \\
\hline $\begin{array}{l}\text { 5. Apa perbedaan akar tunjang dan akar } \\
\text { napas? }\end{array}$ & * & * & * & $\begin{array}{l}3 \text { dari } 11 \\
\text { siswa }\end{array}$ \\
\hline 6. 15. Apakah abrasi dan erosi itu sama? & $\begin{array}{l}3 \text { dari } 10 \\
\text { siswa }\end{array}$ & $\begin{array}{l}5 \text { dari } 10 \\
\text { siswa }\end{array}$ & & \\
\hline $\begin{array}{l}\text { 7. Apakah pembuatan kompos secara alami } \\
\text { atau dengan cara menimbun sampah } \\
\text { organik di dalam tanah dapat merusak } \\
\text { unsur tanah? }\end{array}$ & & & & $\begin{array}{l}7 \text { dari } 10 \\
\text { siswa }\end{array}$ \\
\hline
\end{tabular}

\section{SIMPULAN}

Penelitian ini mendapatkan hasil bahwa guru di SD N Purnama mengalami miskonsepsi pada materi IPA. Miskonsepsi ini terjadi dalam KD 3.1. Menganalisis hubungan antara bentuk dan fungsi bagian tubuh pada hewan dan tumbuhan dan 3.8. Menjelaskan pentingnya upaya keseimbangan dan pelestarian sumber daya alam di lingkungannya. Khususnya pada pertanyaan 1, 4, 5, 7, 9, 15, dan 17. Bapak Agung sendiri memiliki miskonsepsi pada pertanyaan nomor 4, 9 dan 15 sedangkan Ibu Sari mengalami miskonsepsi pada pertanyaan nomor 1, 5, 7, 9, dan 17. Jika dilihat dari materi yang mengalami miskonsepsi, Bapak Agung mengalami miskonsepsi pada materi bagian tubuh tumbuhan (khususnya bunga dan akar) dan upaya keseimbangan alam sedangkan Ibu Sari mengalami miskonsepsi pada materi bagian 
tubuh tumbuhan dan upaya keseimbangan alam. Berdasarkan tanggapan dari pertanyaan Ibu Sari memiliki miskonsepsi yang lebih banyak jika dibandingkan dengan Bapak Agung. Hal ini mungkin dikarenakan Bapak Agung sudah mengajar 14 tahun sedangkan Ibu Sari sudah mengajar 9 tahun, jadi Bapak Agung sudah lebih lama terjun sebagai guru di SD Negeri Purnama.

\section{REFERENSI}

Patton, M. Q. 2002. Qualitative Research \& Evaluation Method (3rd ed). USA: Sage Publication Inc.

Sumantoro dan Hermana, Dodo. 2013. Ayo Belajar Ilmu Pengetahuan Alam Kelas 4 SD. Yogyakarta: Kanisius.

Evahelda, dkk.2017. Sifat fisik dan kimia dari Nektar Pohon Karet di Kabupaten Bangka Tengah, Indonesia. Agritech. Vol 37, No 4, November 2017, Hal. 363-368. https://jurnal.ugm.ac.id/agritech/. Diunduh tanggal 15 Februari 2019

Haryanto. 2016. Sains untuk SD/MI Kelas IV. Jakarta: PT Gelora Aksara Pratama.

Suparno, Paul. 2005. Miskonsepsi dan Perubahan Konsep dalam Pendidikan Fisika. Jakarta: PT Grasindo Anggota Ikapi

Kemendikbd. 2018. Mengenai TIMSS. Dipetik Januari, 15, 23:55, 2018, dari https://pusendik.kemendikbud.go.id/seminar/uploud/Hasil\%20Seminar\%20Puspendik \%202016TIMSSinfografic.pdf. 